\title{
Analisa Usability Aplikasi e-LMA Sebagai e-Learning Menggunakan Metode USE Questionnaire
}

\author{
Usability Analysis of e-LMA Applications as E-learning Using the \\ USE Questionnaire Method \\ Noordin Asnawi \\ Universitas PGRI Madiun \\ Jurusan Sistem Informasi, Fakultas Teknik, UNIPMA \\ e-mail: noordin_asnawi@unipma.ac.id
}

\begin{abstract}
Abstrak - e-LMA (elearning UNIPMA) merupakan aplikasi yang dikembangkan UNIPMA dengan tujuan untuk digunakan sebagai sistem pembelajaran daring atau bisa disebut sebagai e-learning. Aplikasi ini dikembangkan dengan menggunakan layanan LMS (Learning Management Systems) yang berbasis aplikasi Moodle. Di UNIPMA aplikasi ini masih baru digunakan, maka dalam penelitian ini akan dilakukan pengukuran usability (kebergunaan) untuk mengetahui tingkat kebergunaan dari aplikasi ini. Pengukuran dilakukan dengan menggunakan tool USE Questionnaire dengan menyebar angket kepada responden. Dari tool tersebut dapat dijadikan pertanyaan-pertanyaan dalam kuisioner sebanyak 30 pertanyaan yang terbagi dalam 4 faktor sesuai dengan faktor-faktor pada USE questionnaire yaitu usefulness, satisfaction, ease of use, dan ease of learning. Responden yang digunakan adalah dosen yang telah menggunakan aplikasi e-LMA di lingkup Universitas PGRI Madiun. Hasil angket dilakukan pengukuran dengan menggunakan skala likert. Dalam penelitian ini menggunakan 4 skala untuk menegaskan pilihan penilaian, supaya tidak ada pilihan jawaban yang berada ditengah-tengah (netral/sedang/cukup/ragu-ragu). Dari hasil pengukuran dapat disimpulkan bahwa aplikasi e-LMA yang digunakan sebagai e-learning di Universitas PGRI Madiun memiliki nilai usability yang baik.
\end{abstract}

Kata kunci-e-LMA; LMS; skala likert; usability; USE questionnaire;

\begin{abstract}
Abstrac - e-LMA (elearning UNIPMA) is an application developed by UNIPMA with the aim of being used as an online learning system or can be referred to as e-learning. This application was developed using an LMS (Learning Management Systems) service based on the Moodle application. In UNIPMA this application is still newly used, so in this study usability measurements will be carried out to determine the level of usability of this application. Measurements were made using the USE Questionnaire tool by distributing questionnaires to respondents. From these tools, 30 questions can be used in the questionnaire, which are divided into 4 factors according to the factors in the USE questionnaire, namely usefulness, satisfaction, ease of use, and ease of learning. The respondents used are lecturers who have used the e-LMA application within the scope of the Universitas PGRI Madiun. The results of the questionnaire were measured using a Likert scale. In this study using 4 scales to confirm the choice of assessment, so that there are no answer choices that are in the middle (neutral / moderate / sufficient / doubtful). From the measurement results, it can be concluded that the e-LMA application used as elearning at the University of PGRI Madiun has a good usability value.
\end{abstract}

Keywords - e-LMA; LMS; likert scale; usability; USE questionnaire; 


\section{Pendahuluan}

Kemajuan teknologi pada saat ini membuat kebutuhan akan TIK (Teknologi Informasi dan Komunikasi) meningkat dengan pesat. Pada saat ini kebutuhan banyak orang sebagian besar terpenuhi oleh sistem online. Sangat banyak aplikasi-aplikasi yang dibuat untuk mempermudah pekerjaan maupun kebutuhan manusia, misalnya untuk belajar, berbelanja, berpergian, dan lain sebagainya. Begitupun juga dalam dunia pendidikan, banyak aplikasi berbentuk online yang dimanfaatkan dalam dunia pendidikan, misalnya website sekolah maupun kampus, sistem informasi akademik, dan lain-lain.

Selain itu terdapat aplikasi online yang digunakan dalam sistem pembelajaran, misalnya dengan mengembangkan aplikasi $e$ learning. Aplikasi tersebut dapat dikembangkan sesuai dengan keinginan dengan bantuan programmer, atau langsung menggunakan layanan LMS (Learning Management Systems) yang bersifat open source atau bebas digunakan dan dikembangkan.

Universitas PGRI Madiun (UNIPMA) mengembangkan aplikasi yang digunakan dalam sistem pembelajaran sebagai $e$ learning yang berbasiskan LMS Moodle dengan nama e-LMA (elearning UNIPMA). Aplikasi ini termasuk aplikasi yang baru digunakan, khususnya di program studi Sistem Informasi UNIPMA. Pada program studi ini mulai menggunakan layanan aplikasi e-LMA sebagai e-learning. Namun, penggunaan aplikasi ini belum menyeluruh kepada semua dosen di UNIPMA.

Untuk mengetahui tingkat usability penggunaan aplikasi ini akan dilakukan pengukuran tingkat usability dengan menggunakan bantuan tool USE Questionnaire, dimana tool ini dapat digunakan untuk penyusunan pertanyanpertanyaan dalam kuisioner. Sedangkan pemberian nilai digunakan skala likert dengan skala 1 sampai 4 , yang nantinya digunakan untuk perumusan yang menghasilkan nilai akhir untuk hasil analisis.
II. LANDASAN TEORI

\subsection{LMS (Learning Management Systems)}

LMS adalah aplikasi perangkat lunak banyak pengguna (multiuser), biasanya diakses melalui web browser. Aplikasi ini membantu organisasi untuk mengelola kegiatan pelatihan, kursus mandiri, dan program pembelajaran campuran [1].

Terdapat beberapa layanan aplikasi yang dapat digunakan sebagai LMS yaitu seperti Black-board, Desire2Learn, Angel, eCollege, Sakai dan Moodle [2]. Selain itu ada lagi contoh LMS yang lain seperti Google Classroom dan Edmodo.

\subsection{Usability (Kegunaan)}

Ada beberapa definisi mengenai usability, antara lain:

a. Definisi dari ISO

Definisi usability yang paling terkenal adalah dari ISO, International Organization for Standardization (9241-11): "sejauh mana produk dapat digunakan oleh pengguna tertentu untuk mencapai tujuan yang ditentukan dengan efektifitas, efisiensi, dan kepuasan dalam konteks yang ditentukan untuk digunakan" [3] [4].

b. Definisi dari Jakob Nielsen

Mendefinisikan usability sebagai ukuran kualitas pengalaman pengguna ketika berinteraksi dengan produk atau sistem apakah situs web, aplikasi perangkat lunak, teknologi bergerak, maupun peralatan-peralatan lain yang dioperasikan oleh pengguna [5].

Usability adalah atribut kualitas yang menilai seberapa mudah antarmuka pengguna (produk) digunakan. Hal ini juga mengacu pada metode untuk meningkatkan kemudahan pengguna selama proses menggunakan produk. Usability ditentukan oleh 5 komponen kualitas, yaitu: [6] [7]

1) Learnability : seberapa mudah bagi pengguna untuk menyelesaikan tugas-tugas dasar saat pertama kali menggunakan produk? 
2) Efficiency : setelah pengguna mempelajari produk, seberapa cepat mereka dapat mengerjakan tugas?

3) Memorability : saat pengguna kembali ke produk setelah beberapa saat tidak menggunakannya, seberapa mudah mereka dapat menggunakannya kembali?

4) Errors : berapa banyak kesalahan yang dilakukan pengguna, seberapa parah kesalahan ini, dan seberapa mudah mereka memperbaiki kesalahan?

5) Satisfaction : seberapa menyenangkan menggunakan produk?

c. Definisi dari Joseph Dumas dan Janice Redish

Menurut Joseph Dumas dan Janice Redish (1999) usability beararti bahwa orang yang menggunakan produk, dapat menggunakannya dengan cepat dan mudah untuk menyelesaikan tugas. Hal ini bersandar pada 4 poin, yaitu: [8]

1) Usability berarti berfokus pada pengguna,

2) Orang menggunakan produk untuk menjadi produktif,

3) Pengguna adalah orang yang sibuk yang berusaha menyelesaikan tugas, dan

4) Pengguna memutuskan kapan bahwa suatu produk mudah digunakan.

Sebuah produk atau layanan dapat memenuhi tingkat usability jika memiliki kriteria antara lain: useful (berguna); efficient (efisien); effective (efektif); satisfying (memuaskan); learnable (mudah dipelajari); dan accessible (mudah diakses).

Dari masing-masing kriteria tersebut dapat dijelaskan seperti berikut ini : [9]

1) Usefulness

Sejauh mana produk memungkinkan pengguna untuk mencapai tujuannya, dan merupakan penilaian terhadap kesediaan pengguna untuk menggunakannya.

2) Efficiency

Merupakan kecepatan dimana tujuan pengguna dapat dicapai secara akurat dan lengkap.

3) Effectiveness

Sejauh mana produk berperilaku seperti pengguna dan kemudahan pengguna untuk menggunakannya sesuai dengan apa yang diinginkan.

4) Learnability

Merupakan bagian dari efektivitas dan berkaitan dengan kemampuan pengguna untuk mengoperasikan sistem.

5) Satisfaction

Mengacu pada persepsi pengguna, perasaan, dan pendapat pengguna, biasanya diperoleh melalui pertanyaan tertulis dan lisan.

6) Accessibility

Mengacu pada akses terhadap produk yang dibutuhkan untuk mencapai suatu tujuan.

\subsection{USE Questionnaire}

Analisis tingkat usability dapat dilakukan dengan menggunakan kuisioner yang kemudian dilakukan pengukuran nilai. Kuisioner yang digunakan dalam menyusun pertanyaan-pertanyaan yang akan diberikan dapat menggunakan tool USE Questionnaire, dimana tool ini terdiri dari 30 item yang dapat digunakan dalam menyusun pertanyaan.

USE Questionnaire dikembangkan oleh Arnold Lund dan rekan di Ameritech, U.S WEST Advanced Technologies. USE merupakan singkatan dari Usefulness (kegunaan), Satisfction (Kepuasan), dan Ease of use (Kemudahan penggunaan). Pada faktor Ease of use dapat dibagi menjadi 2 faktor, yaitu Ease of Learning (kemudahan belajar) dan Ease of Use (kemudahan penggunaan) [10]

\subsection{Skala Likert}

Menanggapi sulitnya mengukur karakter dan ciri kepribadian, Likert 
(1932) mengembangkan prosedur untuk mengukur skala sikap. Skala likert yang asli menggunakan serangkaian pertanyaan dengan lima alternatif tanggapan yaitu: (1) sangat setuju, (2) setuju, (3) ragu-ragu, (4) tidak setuju, dan (5) sangat tidak setuju.

Dia menggabungkan tanggapan dari rangkaian pertanyaan untuk membuat pengukuran sikap. Analisis datanya didasarkan pada skor gabungan dari rangkaian pertanyaan yang mewakili skala sikap [11].

Menurut Guritno, dkk (dalam Asnawi, $\mathrm{N})$, skala likert digunakan untuk mengukur sikap, pendapat, dan persepsi seseorang atau sekelompok orang tentang kejadian atau gejala sosial. Dalam penelitian gejala sosial, peneliti telah menetapkan secara spesifik skalanya dan selanjutnya disebut variabel penelitian [12].

Pada skala likert biasanya digunakan skala pengukuran sebanyak 5 skala. Terdapat dua bentuk pertanyaan dalam skala likert, yaitu bentuk pertanyaan positif untuk mengukur skala positif dengan pemberian skor $5 ; 4 ; 3 ; 2 ; 1$, dan bentuk pertanyaan negatif untuk mengukur skala negatif dengan skor $1 ; 2 ; 3 ; 4 ; 5$ [13] . Tetapi dalam penelitian ini menggunakan 4 skala untuk menegaskan pilihan penilaian, supaya tidak ada pilihan jawaban yang berada ditengah-tengah (netral/sedang/cukup/ragu-ragu).

\section{METODE}

3.1 Populasi dan Sampel Penelitian

Populasi berkaitan dengan seluruh kelompok orang, peristiwa, atau benda yang menjadi pusat perhatian penelitian untuk diteliti. Sampel merupakan suatu bagian dari populasi. Hal ini mencakup sejumlah anggota yang dipilih dari populasi [12].

Menurut Arikunto (dalam Junaidi dan Susanti, 2019) populasi merupakan keseluruhan dari subjek penelitian. Populasi individu yang memiliki sifat yang sama walaupun prosentase kesamaan sedikit. Sedangkan sampel merupakan sebagian atau wakil populasi yang diteliti. [14].

Jumlah responden yang dilibatkan dalam penelitian ini adalah sebanyak 17 responden dari suatu populasi yaitu dosen Universitas PGRI Madiun yang menggunakan aplikasi e-LMA.

\subsection{Metode Pengumpulan Data}

Metode pengumpulan data dilakukan dengan metode angket yaitu menyebarkan kuisioner kepada dosen dengan menggunakan layanan Google Formulir.

Google formulir merupakan salah satu sistem berupa template formulir yang dapat dimanfaatkan untuk tujuan mendapatkan informasi pengguna. Syarat untuk menggunakannya hanya dengan mempunyai akun Google [15].

Pengukuran hasil dari angket dilakukan dengan menggunakan skala likert yang terbagi dalam skala 1 sampai 4 yaitu Sangat Tidak Setuju (STS), Tidak Setuju (TS), Setuju (S), dan Sangat Setuju (SS), dengan skor masing-masing skala pada $\underline{\text { Tabel } 1}$ berikut ini:

Tabel 1. Nilai skala

\begin{tabular}{|l|c|c|c|c|}
\hline Pertanyaan & STS & TS & S & SS \\
\hline Nilai & 1 & 2 & 3 & 4 \\
\hline
\end{tabular}

\subsection{Alur Penelitian}

Pada penelitian yang akan dilakukan, langkah-langkah yang akan dilakukan untuk mencapai tujuan yang diinginkan adalah seperti pada Gambar 1 berikut ini: 


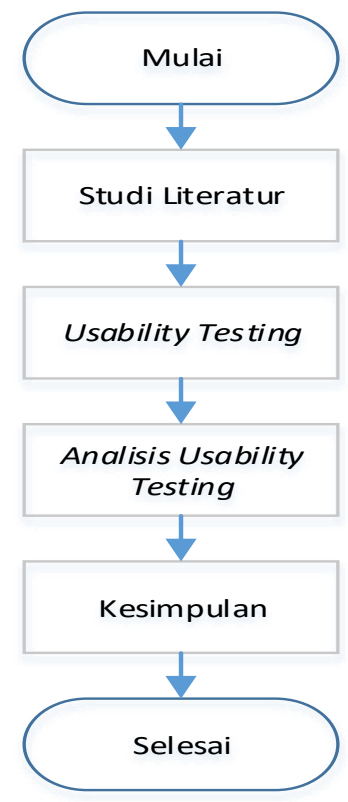

Gambar 1. Alur Penelitian

Keterangan:

Studi literatur : Pencarian referensi mengenai LMS, usability, USE questionnaire, dan skala likert

Usability testing : penyebaran angket kepada responden

Analisis : perekapan hasil pengisian usability testing angket dan penghitungan nilai usability

Kesimpulan : penarikan kesimpulan hasil dari nilai usability

IV. HASIL

\subsection{Usability testing}

Langkah awal dalam usability testing ini yaitu dengan menyusun pertanyaanpertanyaan yang akan digunakan sebagai angket dan disebarkan kepada responden yang telah menggunakan aplikasi e-LMA di UNIPMA, dimana populasi tersebut ialah dosen. Pertanyaan-pertanyaan ini mengacu pada 30 item pernyataan di dalam tool USE questionnaire.

Dari tool tersebut dapat dijadikan pertanyaan-pertanyaan dalam kuisioner sebanyak 30 pertanyaan yang terbagi dalam 4 faktor sesuai dengan faktor-faktor pada USE questionnaire yaitu usefulness, satisfaction, ease of use, dan ease of learning.
Pertanyaan-pertanyaan tersebut dapat dilihat pada Tabel 2 berikut ini:

Tabel 2. Daftar pertanyaan

\begin{tabular}{|c|c|c|c|c|c|c|}
\hline \multirow[b]{2}{*}{ Faktor } & \multirow[b]{2}{*}{ No. } & \multirow[b]{2}{*}{ Pertanyaan } & \multicolumn{4}{|c|}{ Penilaian } \\
\hline & & & $\begin{array}{l}\mathbf{S} \\
\mathbf{T} \\
\mathbf{S}\end{array}$ & $\begin{array}{l}\mathbf{T} \\
\mathbf{S}\end{array}$ & $\mathbf{S}$ & $\begin{array}{l}\text { S } \\
\text { S }\end{array}$ \\
\hline \multirow{8}{*}{$\begin{array}{c}\text { Useful } \\
\text { ness }\end{array}$} & 1 & $\begin{array}{l}\text { Aplikasi ini } \\
\text { membantu } \\
\text { saya lebih } \\
\text { efektif? }\end{array}$ & & & & \\
\hline & 2 & $\begin{array}{l}\text { Aplikasi ini } \\
\text { membantu } \\
\text { saya lebih } \\
\text { produktif? }\end{array}$ & & & & \\
\hline & 3 & $\begin{array}{l}\text { Apalikasi ini } \\
\text { berguna? }\end{array}$ & & & & \\
\hline & 4 & $\begin{array}{lr}\text { Aplikasi } & \text { ini } \\
\text { memberi } & \text { saya } \\
\text { kontrol } & \text { lebih } \\
\text { besar } & \text { atas } \\
\text { aktivitas } & \\
\text { belajar } & \\
\text { mengajar? } & \end{array}$ & & & & \\
\hline & 5 & $\begin{array}{l}\text { Aplikasi ini } \\
\text { membuat } \\
\text { pekerjaan yang } \\
\text { ingin saya } \\
\text { selesaikan } \\
\text { lebih mudah } \\
\text { dilakukan? }\end{array}$ & & & & \\
\hline & 6 & $\begin{array}{l}\text { Aplikasi ini } \\
\text { dapat } \\
\text { menghemat } \\
\text { waktu saat } \\
\text { saya } \\
\text { menggunakann } \\
\text { ya? }\end{array}$ & & & & \\
\hline & 7 & $\begin{array}{l}\text { Aplikasi ini } \\
\text { memenuhi } \\
\text { kebutuhan } \\
\text { saya? }\end{array}$ & & & & \\
\hline & 8 & $\begin{array}{l}\text { Aplikasi ini } \\
\text { melakukan } \\
\text { semua yang } \\
\text { saya harapkan } \\
\text { untuk } \\
\text { dilakukan? }\end{array}$ & & & & \\
\hline \multirow{3}{*}{$\begin{array}{c}\text { Ease of } \\
\text { use }\end{array}$} & 1 & $\begin{array}{l}\text { Aplikasi ini } \\
\text { mudah } \\
\text { digunakan? }\end{array}$ & & & & \\
\hline & 2 & $\begin{array}{ll}\text { Aplikasi ini } \\
\text { sederhana } \\
\text { untuk } \\
\text { digunakan? }\end{array}$ & & & & \\
\hline & 3 & $\begin{array}{l}\text { Aplikasi ini } \\
\text { user friendly? }\end{array}$ & & & & \\
\hline
\end{tabular}




\begin{tabular}{|c|c|c|c|c|c|c|}
\hline \multirow{10}{*}{ Faktor } & \multirow[b]{2}{*}{ No. } & \multirow[b]{2}{*}{ Pertanyaan } & \multicolumn{4}{|c|}{ Penilaian } \\
\hline & & & $\begin{array}{l}\mathbf{S} \\
\mathbf{T} \\
\mathbf{S}\end{array}$ & $\begin{array}{l}\mathbf{T} \\
\mathbf{S}\end{array}$ & $\mathbf{S}$ & $\begin{array}{l}\mathbf{S} \\
\mathbf{S}\end{array}$ \\
\hline & 4 & $\begin{array}{l}\text { Aplikasi ini } \\
\text { membutuhkan } \\
\text { langkah- } \\
\text { langkah yang } \\
\text { sedikit untuk } \\
\text { mencapai } \\
\text { tujuan? }\end{array}$ & & & & \\
\hline & 5 & $\begin{array}{l}\text { Aplikasi ini } \\
\text { fleksibel? }\end{array}$ & & & & \\
\hline & 6 & $\begin{array}{l}\text { Aplikasi ini } \\
\text { saya gunakan } \\
\text { dengan } \\
\text { mudah? }\end{array}$ & & & & \\
\hline & 7 & $\begin{array}{l}\text { Aplikasi ini } \\
\text { saya gunakan } \\
\text { tanpa instruksi } \\
\text { tertulis? }\end{array}$ & & & & \\
\hline & 8 & $\begin{array}{l}\text { Aplikasi ini } \\
\text { konsisten } \\
\text { ketika saya } \\
\text { gunakan? }\end{array}$ & & & & \\
\hline & 9 & $\begin{array}{l}\text { Aplikasi ini } \\
\text { mudah disukai } \\
\text { untuk } \\
\text { pengguna } \\
\text { baru? }\end{array}$ & & & & \\
\hline & 10 & $\begin{array}{l}\text { Saya dapat } \\
\text { memulihkan } \\
\text { dengan cepat } \\
\text { dan mudah } \\
\text { ketika } \\
\text { membuat } \\
\text { kesalahan? }\end{array}$ & & & & \\
\hline & 11 & $\begin{array}{l}\text { Saya berhasil } \\
\text { menggunakann } \\
\text { ya dengan baik } \\
\text { setiap waktu? }\end{array}$ & & & & \\
\hline & 1 & $\begin{array}{lr}\text { Saya belajar } \\
\text { menggunakann } \\
\text { ya dengan } \\
\text { cepat? }\end{array}$ & & & & \\
\hline Ease of & 2 & $\begin{array}{l}\text { Saya mudah } \\
\text { mengingat } \\
\text { bagaimana } \\
\text { cara } \\
\text { menggunakann } \\
\text { ya? }\end{array}$ & & & & \\
\hline$g$ & 3 & $\begin{array}{l}\text { Saya mudah } \\
\text { memperlajari } \\
\text { untuk } \\
\text { menggunakann } \\
\text { ya? }\end{array}$ & & & & \\
\hline & 4 & $\begin{array}{l}\text { Saya dengan } \\
\text { cepat mahir } \\
\text { dalam } \\
\text { menggunakann } \\
\text { ya? }\end{array}$ & & & & \\
\hline
\end{tabular}

\begin{tabular}{|c|c|c|c|c|c|c|}
\hline \multirow[b]{2}{*}{ Faktor } & \multirow[b]{2}{*}{ No. } & \multirow[b]{2}{*}{ Pertanyaan } & \multicolumn{4}{|c|}{ Penilaian } \\
\hline & & & $\begin{array}{l}\mathbf{S} \\
\mathbf{T} \\
\mathbf{S}\end{array}$ & $\begin{array}{l}\mathbf{T} \\
\mathbf{S}\end{array}$ & $\mathbf{S}$ & $\begin{array}{l}\mathbf{S} \\
\mathbf{S}\end{array}$ \\
\hline \multirow{7}{*}{$\begin{array}{l}\text { Satisfa } \\
\text { ction }\end{array}$} & 1 & $\begin{array}{l}\text { Saya puas } \\
\text { dengan } \\
\text { aplikasi ini? }\end{array}$ & & & & \\
\hline & 2 & $\begin{array}{l}\text { Saya akan } \\
\text { merekomendas } \\
\text { ikan aplikasi } \\
\text { ini kepada } \\
\text { teman? }\end{array}$ & & & & \\
\hline & 3 & $\begin{array}{l}\text { Aplikasi ini } \\
\text { menyenangkan } \\
\text { untuk } \\
\text { digunakan? }\end{array}$ & & & & \\
\hline & 4 & $\begin{array}{lr}\text { Cara } & \text { kerja } \\
\text { aplikasi } & \text { ini } \\
\text { sudah } & \text { seperti } \\
\text { yang } & \text { saya } \\
\text { inginkan? } & \end{array}$ & & & & \\
\hline & 5 & $\begin{array}{l}\text { Aplikasi ini } \\
\text { luar biasa? }\end{array}$ & & & & \\
\hline & 6 & $\begin{array}{l}\text { Saya merasa } \\
\text { perlu } \\
\text { memilikinya? }\end{array}$ & & & & \\
\hline & 7 & $\begin{array}{l}\text { Aplikasi ini } \\
\text { nyaman untuk } \\
\text { digunakan? }\end{array}$ & & & & \\
\hline
\end{tabular}

\subsection{Analisis usability testing}

Setelah dilakukan penyebaran angket secara daring dengan 30 pertanyaan dalam kuisioner kepada 17 responden, maka selanjutnya dilakukan perekapan terhadap hasil kuisioner. Penilaian dilakukan menggunakan skala likert dengan skala 1 sampai 4 yaitu STS (1), TS (2), S (3), dan SS (4).

Hasil rekapan tersebut dapat dilihat pada Tabel 3 berikut ini:

Tabel 3. Hasil rekap penilaian

\begin{tabular}{|c|c|c|c|c|c|c|}
\hline \multirow[b]{2}{*}{ Faktor } & \multirow[b]{2}{*}{ No. } & \multirow[b]{2}{*}{ Pertanyaan } & \multicolumn{4}{|c|}{ Penilaian } \\
\hline & & & $\begin{array}{l}\mathbf{S} \\
\mathbf{T} \\
\mathbf{S}\end{array}$ & $\begin{array}{l}\mathbf{T} \\
\mathbf{S}\end{array}$ & $\mathbf{S}$ & $\begin{array}{l}\mathbf{S} \\
\mathbf{S}\end{array}$ \\
\hline \multirow{3}{*}{$\begin{array}{c}\text { Useful } \\
\text { ness }\end{array}$} & 1 & $\begin{array}{l}\text { Aplikasi ini } \\
\text { membantu } \\
\text { saya lebih } \\
\text { efektif? }\end{array}$ & & & 4 & 13 \\
\hline & 2 & $\begin{array}{l}\text { Aplikasi ini } \\
\text { membantu } \\
\text { saya lebih } \\
\text { produktif? }\end{array}$ & & & 8 & 9 \\
\hline & 3 & $\begin{array}{l}\text { Apalikasi ini } \\
\text { berguna? }\end{array}$ & & & 2 & 15 \\
\hline
\end{tabular}




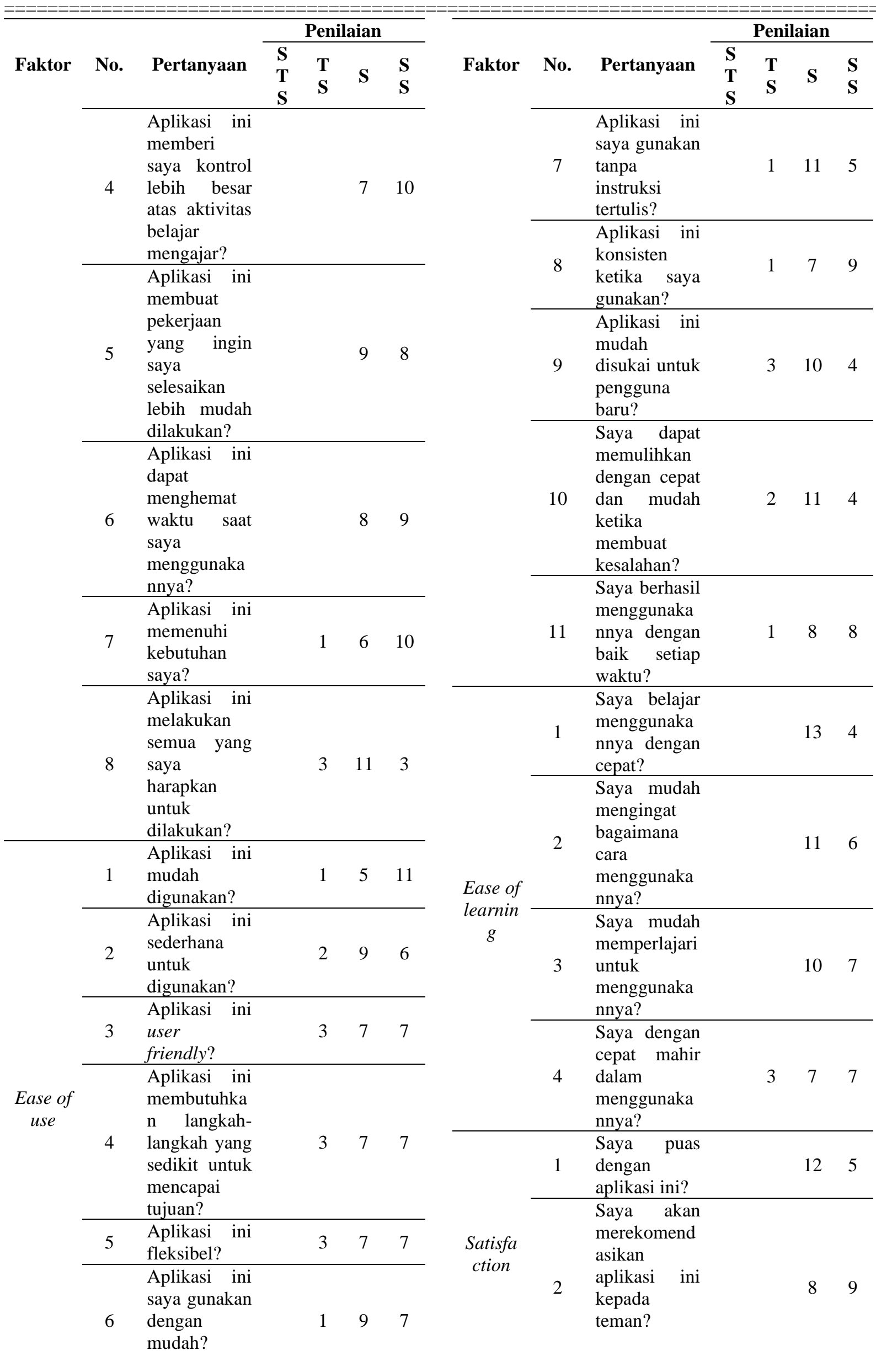




\begin{tabular}{|c|c|c|c|c|c|c|}
\hline \multirow[b]{2}{*}{ Faktor } & \multirow[b]{2}{*}{ No. } & \multirow[b]{2}{*}{ Pertanyaan } & \multicolumn{4}{|c|}{ Penilaian } \\
\hline & & & $\begin{array}{l}\mathbf{S} \\
\mathbf{T} \\
\mathbf{S}\end{array}$ & $\begin{array}{l}\mathbf{T} \\
\mathbf{S}\end{array}$ & $\mathbf{S}$ & $\begin{array}{l}\mathbf{S} \\
\mathbf{S}\end{array}$ \\
\hline & 3 & $\begin{array}{l}\text { Aplikasi ini } \\
\text { menyenangk } \\
\text { an untuk } \\
\text { digunakan? }\end{array}$ & & 1 & 10 & 6 \\
\hline & 4 & $\begin{array}{l}\text { Cara kerja } \\
\text { aplikasi ini } \\
\text { sudah seperti } \\
\text { yang saya } \\
\text { inginkan? }\end{array}$ & & 2 & 10 & 5 \\
\hline & 5 & $\begin{array}{l}\text { Aplikasi ini } \\
\text { luar biasa? }\end{array}$ & & 2 & 12 & 3 \\
\hline & 6 & $\begin{array}{l}\text { Saya merasa } \\
\text { perlu } \\
\text { memilikinya } \\
\text { ? }\end{array}$ & & & 8 & 9 \\
\hline & 7 & $\begin{array}{l}\text { Aplikasi ini } \\
\text { nyaman } \\
\text { untuk } \\
\text { digunakan? }\end{array}$ & & & 9 & 8 \\
\hline
\end{tabular}

Tabel 3 menunjukkan hasil rekapan pengisian angket dari ke-17 responden dari masing-masing faktor pada USE Questionnaire.

Kemudian dari hasil tersebut dilakukan pengolahan nilai dari jumlah isian dari masing-masing penilaian (STS, TS, S, dan SS) dengan mengkalikan jumlah isian dengan nilai dari penilaian. Hasilnya seperti pada Tabel 4 berikut:

Tabel 4. Hasil pengolahan nilai

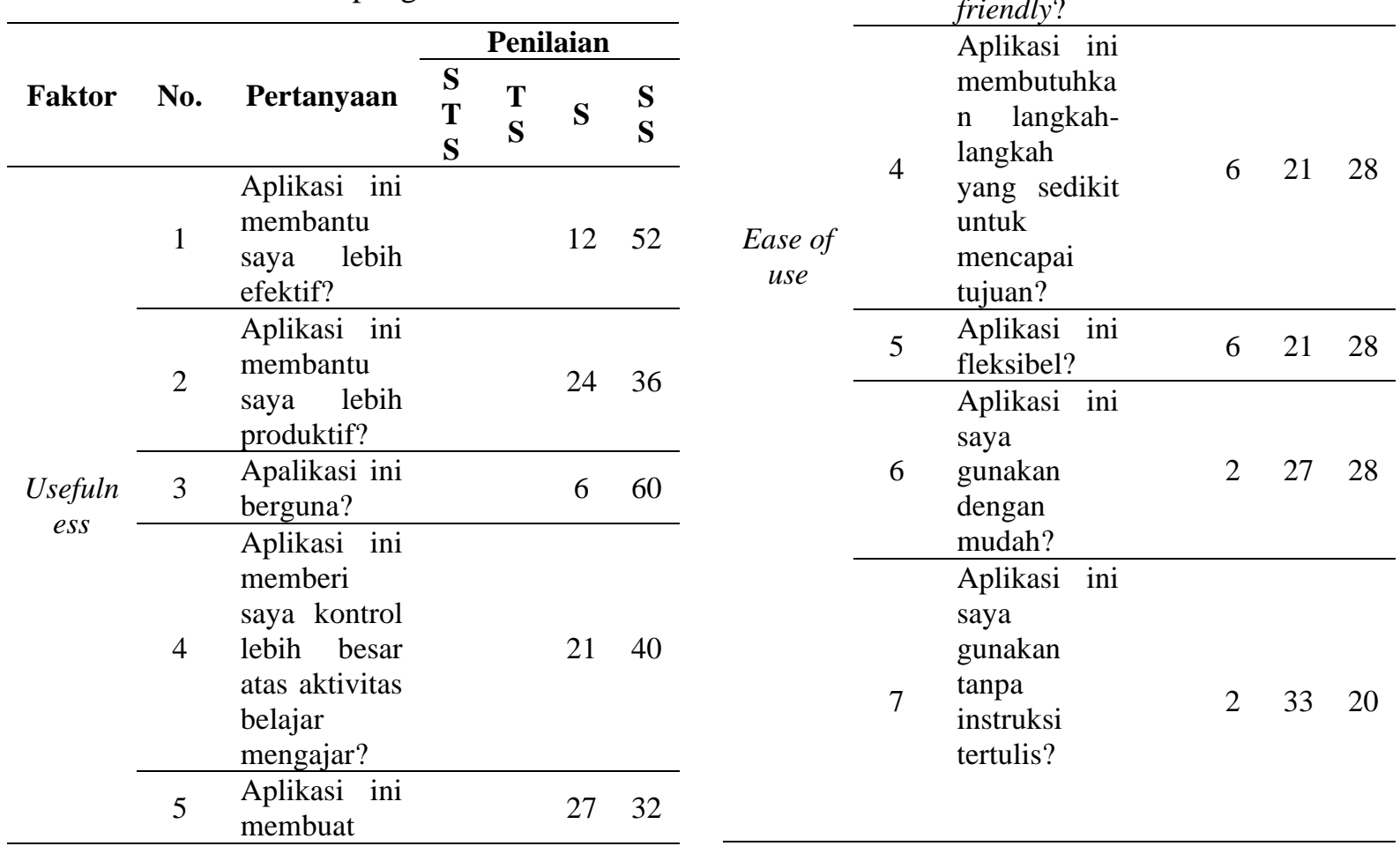




\begin{tabular}{|c|c|c|c|c|c|c|c|c|c|c|c|c|c|}
\hline \multirow{8}{*}{ Faktor } & \multirow[b]{2}{*}{ No. } & \multirow[b]{2}{*}{ Pertanyaan } & \multicolumn{4}{|c|}{ Penilaian } & \multirow[b]{2}{*}{ Faktor } & \multirow[b]{2}{*}{ No. } & \multirow[b]{2}{*}{ Pertanyaan } & \multicolumn{4}{|c|}{ Penilaian } \\
\hline & & & $\begin{array}{l}\mathbf{S} \\
\mathbf{T} \\
\mathbf{S}\end{array}$ & $\begin{array}{l}\mathbf{T} \\
\mathbf{S}\end{array}$ & $\mathbf{S}$ & $\begin{array}{l}\mathbf{S} \\
\mathbf{S}\end{array}$ & & & & $\begin{array}{l}\mathbf{S} \\
\mathbf{T} \\
\mathbf{S}\end{array}$ & $\begin{array}{l}\mathbf{T} \\
\mathbf{S}\end{array}$ & $\mathbf{S}$ & $\begin{array}{l}\mathbf{S} \\
\mathbf{S}\end{array}$ \\
\hline & 8 & $\begin{array}{l}\text { Aplikasi ini } \\
\text { konsisten } \\
\text { ketika saya } \\
\text { gunakan? }\end{array}$ & & 2 & 21 & 36 & & 4 & $\begin{array}{l}\text { Cara kerja } \\
\text { aplikasi ini } \\
\text { sudah seperti } \\
\text { yang saya }\end{array}$ & & 4 & 30 & 20 \\
\hline & & Aplikasi ini & & & & & & & inginkan? & & & & \\
\hline & 0 & $\begin{array}{l}\text { mudah } \\
\text { disukai }\end{array}$ & & 6 & 20 & 16 & & 5 & $\begin{array}{l}\text { Aplikasi ini } \\
\text { luar biasa? }\end{array}$ & & 4 & 36 & 12 \\
\hline & 9 & $\begin{array}{l}\text { untuk } \\
\text { pengguna } \\
\text { baru? }\end{array}$ & & 6 & 30 & 16 & & 6 & $\begin{array}{l}\text { Saya merasa } \\
\text { perlu } \\
\text { memilikinya }\end{array}$ & & & 24 & 36 \\
\hline & & Saya dapat & & & & & & & $?$ & & & & \\
\hline & 10 & $\begin{array}{l}\text { memulihkan } \\
\text { dengan cepat } \\
\text { dan mudah } \\
\text { ketika }\end{array}$ & & 4 & 33 & 16 & & 7 & $\begin{array}{l}\text { Aplikasi ini } \\
\text { nyaman } \\
\text { untuk } \\
\text { digunakan? }\end{array}$ & & & 27 & 32 \\
\hline
\end{tabular}

Tabel 4 menunjukkan hasil dari kesalahan?

Saya

berhasil

11 menggunaka

nnya dengan

$2 \quad 24 \quad 32$

baik setiap

waktu?

Saya belajar

1 menggunaka

nnya dengan

$39 \quad 16$

cepat?

Saya mudah

mengingat

2 bagaimana

cara

menggunaka

Ease of nnya?

learnin

Saya mudah

$g$ memperlajar

3 i untuk

$30 \quad 28$

menggunaka

nnya?

Saya dengan

cepat mahir

$\begin{array}{lllll}4 & \text { dalam } & 6 & 21 & 28\end{array}$

menggunaka

nnya?

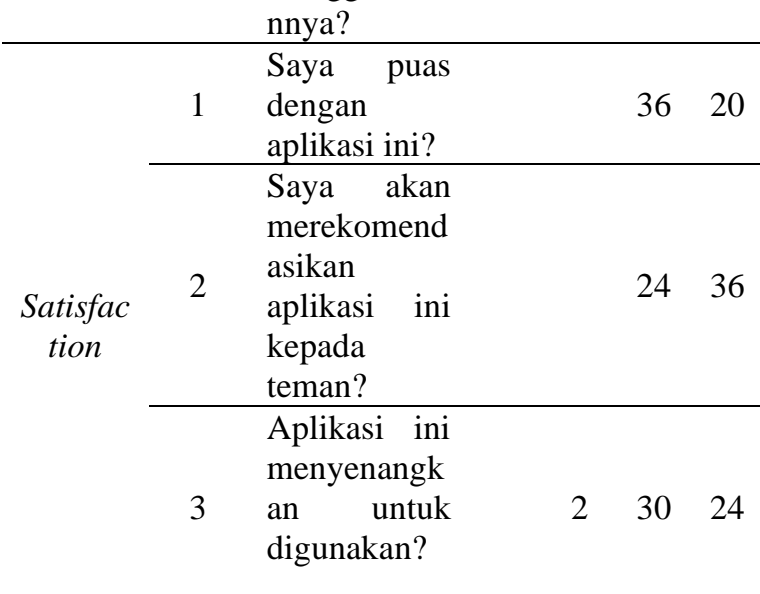

pengolahan nilai dari masing-masing skala dengan jumlah responden yang mengisi masing-masing poin pertanyaan.

Kemudian dari hasil tersebut akan diolah lagi dengan menjumlahkan nilai hasil kali sebelumnya dari masing-masing poin pertanyaan, setelah dijumlahkan kemudian dicari nilai akhir berupa rata-rata nilai dari masing-masing faktor. Hasilnya seperti pada Tabel 5 berikut:

Tabel 5. Hasil Akhir Penilaian

\begin{tabular}{|c|c|c|c|}
\hline Faktor & No. & Pertanyaan & Penilaian \\
\hline \multirow{6}{*}{$\begin{array}{l}\text { Usefuln } \\
\text { ess }\end{array}$} & 1 & $\begin{array}{lr}\text { Aplikasi } & \text { ini } \\
\text { membantu } & \text { saya } \\
\text { lebih efektif? } & \end{array}$ & 3,76 \\
\hline & 2 & $\begin{array}{l}\text { Aplikasi ini } \\
\text { membantu saya } \\
\text { lebih produktif? }\end{array}$ & 3,53 \\
\hline & 3 & $\begin{array}{l}\text { Apalikasi ini } \\
\text { berguna? }\end{array}$ & 3,88 \\
\hline & 4 & $\begin{array}{l}\text { Aplikasi ini } \\
\text { memberi } \\
\text { kontrol lebih besar } \\
\text { atas aktivitas belajar } \\
\text { mengajar? }\end{array}$ & 3,59 \\
\hline & 5 & $\begin{array}{lr}\text { Aplikasi } & \text { ini } \\
\text { membuat pekerjaan } \\
\text { yang ingin saya } \\
\text { selesaikan lebih } \\
\text { mudah dilakukan? }\end{array}$ & 3,47 \\
\hline & 6 & $\begin{array}{lr}\text { Aplikasi ini dapat } \\
\text { menghemat waktu } \\
\text { saat rana } \\
\text { menggunakannya? }\end{array}$ & 3,53 \\
\hline
\end{tabular}




\begin{tabular}{|c|c|c|c|c|c|c|c|}
\hline \multirow[t]{4}{*}{ Faktor } & \multirow{2}{*}{$\begin{array}{c}\text { No. } \\
7\end{array}$} & Pertanyaan & Penilaian & Faktor & No. & Pertanyaan & Penilaian \\
\hline & & $\begin{array}{l}\text { Aplikasi ini } \\
\text { memenuhi } \\
\text { kebutuhan saya? }\end{array}$ & 3,53 & & \multirow[t]{2}{*}{2} & $\begin{array}{l}\text { Saya akan } \\
\text { merekomendasikan } \\
\text { aplikasi ini kepada }\end{array}$ & \multirow[t]{2}{*}{3,53} \\
\hline & \multirow[b]{2}{*}{8} & Aplikasi ini & \multirow[b]{2}{*}{3,00} & & & teman? & \\
\hline & & $\begin{array}{l}\text { melakukan semua } \\
\text { yang saya harapkan } \\
\text { untuk dilakukan? }\end{array}$ & & & \multirow[t]{2}{*}{3} & $\begin{array}{l}\text { Aplikasi ini } \\
\text { menyenangkan } \\
\text { untuk digunakan? }\end{array}$ & \multirow[t]{2}{*}{3,29} \\
\hline & \multirow{2}{*}{1} & Aplikasi ini mudah & \multirow{2}{*}{3,59} & & & & \\
\hline & & digunakan? & & & \multirow[b]{2}{*}{4} & Cara kerja aplikasi & \multirow[b]{2}{*}{3,18} \\
\hline & \multirow[t]{2}{*}{2} & $\begin{array}{lr}\text { Aplikasi } & \text { ini } \\
\text { sederhana } & \text { untuk }\end{array}$ & \multirow[t]{2}{*}{3,24} & & & $\begin{array}{l}\text { ini sudah seperti } \\
\text { yang saya inginkan? }\end{array}$ & \\
\hline & & digunakan? & & & \multirow{2}{*}{5} & Aplikasi ini luar & \multirow{2}{*}{3,06} \\
\hline & \multirow{2}{*}{3} & Aplikasi ini user & \multirow{2}{*}{3,24} & & & biasa? & \\
\hline & & friendly? & & & \multirow{2}{*}{6} & Saya merasa perlu & \multirow{2}{*}{3,53} \\
\hline & & Aplikasi ini & & & & memilikinya? & \\
\hline & 4 & $\begin{array}{l}\text { membutuhkan } \\
\text { langkah-langkah }\end{array}$ & 3,24 & & 7 & $\begin{array}{l}\text { Aplikasi ini nyaman } \\
\text { untuk digunakan? }\end{array}$ & 3,47 \\
\hline
\end{tabular}

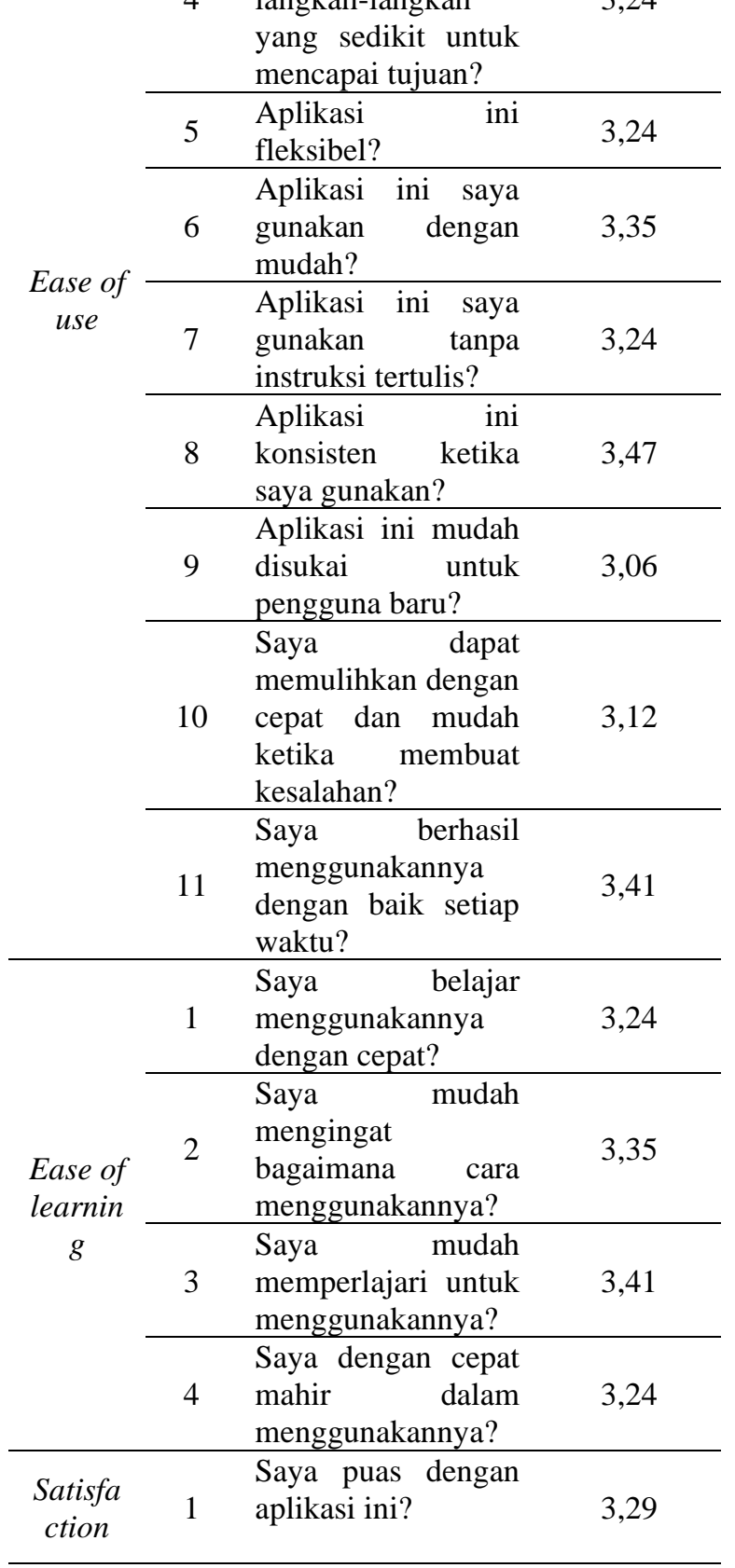

Tabel 5 menunjukkan nilai dari masingmasing poin pertanyaan yang terdapat pada USE questionnaire yaitu pada faktor usefulness, ease of use, ease of learning, dan satisfaction. Pada masing-masing faktor dapat diperoleh nilai rata-rata sebesar: usefulness $=$ 3,54 ; ease of use $=3,29$; ease of learning $=$ 3,31 ; dan satisfaction $=3,34$.

Jika disesuaikan dengan masing-masing faktor pada USE questionnaire, dapat ditarik kesimpulan bahwa aplikasi e-LMA yang digunakan oleh dosen di UNIPMA sebagai $e$ learning memiliki nilai yang sudah baik. Dari hasil nilai tersebut masing-masing faktor dapat disimpulkan seperti berikut ini:

a. Nilai faktor usefulness (kegunaan) sebesar 3,54 yang menunjukkan bahwa aplikasi eLMA telah memiliki kegunaan yang baik, artinya bahwa aplikasi ini berguna jika digunakan sebagai $e$-learning.

b. Nilai faktor ease of use (kemudahan penggunaan) sebesar 3,29 yang menunjukkan bahwa aplikasi e-LMA telah memiliki kemudahan dalam penggunaan yang baik, artinya bahwa aplikasi ini mudah dalam proses penggunaannya.

c. Nilai faktor ease of learning (kemudahan belajar) sebesar 3,31 yang menunjukkan bahwa aplikasi e-LMA telah memiliki kemudahan dalam belajar yang sudah baik, artinya bahwa aplikasi ini mudah dalam proses belajar menggunakannya.

d. Nilai faktor satisfaction (kepuasan) sebesar 3,34 yang menunjukkan bahwa aplikasi e-LMA telah memiliki kepuasan yang baik, artinya bahwa aplikasi ini sudah dirasa memuaskan dalam 
penggunaanya sebagai e-learning. Hal ini dipengaruhi juga oleh faktor ease of use dan ease of learning yang sudah baik yang menyebabkan nilai kepuasan menjadi baik.

\section{KESIMPULAN}

Hasil rekap penilaian usability menggunakan tool USE questionnaire menunjukkan nilai yang baik pada semua faktor usefulness, ease of use, ease of learning, dan satisfaction. Hal ini menunjukkan bahwa aplikasi e-LMA sudah baik digunakan sebagai e-learning di Universitas PGRI Madiun. Harapan kedepan untuk seluruh dosen di UNIPMA dapat menggunakan aplikasi ini sebagai aplikasi penunjang dalam pelaksanaan pembelajaran daring.

\section{DAFTAR PUSTAKA}

"The LMS Guidebook: Learning Management Systems Demystified - Steve Foreman Google Buku." https://books.google.co.id/books?id=a_NADw AAQBAJ\&printsec=frontcover\&dq=learning +management+systems\&hl=id\&sa $=X \& v e d=2$ ahUKEwjbjonh3qftAhVEX30KHRiiAXsQ6A EwAXoECAYQAg\#v=onepage\& $q=$ learning management systems\&f=false (accessed Dec. $16,2020)$.

[2] Y. Kats, Learning management system technologies and software solutions for online teaching: Tools and applications. IGI Global, 2010.

[3] "Usability Testing Essentials: Ready, Set...Test! - Carol M. Barnum - Google Buku."

https://books.google.co.id/books?id=tzX3J81

MAAMC\&pg=PA132\&dq=usability+testing

$\&$ hl=id\&sa $=$ X\&ved=2ahUKEwi_p-

XK5NHtAhVX73MBHbxhDhoQ6AEwBHoE

$\mathrm{CAEQAg \#} \mathrm{v}=$ onepage $\& \mathrm{q}=$ usability

testing \&f $=$ false (accessed Dec. 16, 2020).

[4] B. Beny, H. Yani, and G. M. Ningrum, "Evaluasi Usability Situs Web Kemenkumham Kantor Wilayah Jambi dengan Metode Usability Test dan System Usability Scale," Res. Comput. Inf. Syst. Technol. Manag., vol. 2, no. 1, p. 30, Apr. 2019, doi: 10.25273/research.v2i1.4282.

[5] W. Handiwidjojo and L. Ernawati, "Pengukuran Tingkat Ketergunaan ( Usability ) Sistem Informasi Keuangan Studi Kasus: Duta Wacana Internal Transaction ( Duwit ),' vol. 02, no. 01, 2016.
[6] "Usability 101: Introduction to Usability." https://www.nngroup.com/articles/usability101-introduction-to-usability/ (accessed Dec. $16,2020)$.

[7] J. Karaman, "Usability Analysis of The Mobile-Based Cizgi Rent A Car Application Using The WEBUSE Method," Res. J. Comput. Inf. Syst. Technol. Manag., vol. 3, no. 2 , p. 93, Oct. 2020, doi: 10.25273/research.v3i2.7614.

[8] "A Practical Guide to Usability Testing Joseph S Dumas, Joseph S. Dumas, Janice Redish - Google Buku." https://books.google.co.id/books?id=4lge5k_F $9 \mathrm{EwC} \&$ printsec $=$ frontcover\&dq=usability \&hl $=\mathrm{id} \& \mathrm{sa}=\mathrm{X} \& v e d=2 \mathrm{ahUKEwjg} 7 \mathrm{KDk} 8 \mathrm{qft} A h U X$ WX0KHUj_AsoQ6AEwAXoECAYQAg\#v=o nepage $\& \mathrm{q}=$ usability $\& \mathrm{f}=$ false (accessed Dec. 16, 2020).

[9] C. D. Rubin Jeffrey, "Handbook of Usability." p. 335,2008 .

[10] A. M. Lund, "Measuring usability with the USE questionnaire," Usability interface, vol. 8, no. 2, pp. 3-6, 2001.

[11] H. N. Boone, J. Associate Professor, and D. A. Boone Associate Professor, "Number 2 Article Number 2TOT2," 2012. Accessed: Dec. 16, 2020. [Online]. Available: http://www.joe.org/joe/2012april/tt2p.shtml[8/ 20/20129:07:48AM].

[12] N. Asnawi, "Pengukuran Usability Aplikasi Google Classroom Sebagai E-learning Menggunakan USE Questionnaire (Studi Kasus: Prodi Sistem Informasi UNIPMA)," Res. Comput. Inf. Syst. Technol. Manag., vol. 1, no. 1, p. 17, Apr. 2018, doi: 10.25273/research.v1i1.2451.

[13] V. H. Pranatawijaya, W. Widiatry, R. Priskila, and P. B. A. A. Putra, "Penerapan Skala Likert dan Skala Dikotomi Pada Kuesioner Online," J. Sains dan Inform., vol. 5, no. 2, pp. 128137, 2019, doi: 10.34128/jsi.v5i2.185.

[14] R. Junaidi and F. Susanti, "Pengaruh Gaya Kepemimpinan Dan Budaya Organisasi Terhadap Kinerja Pegawai Pada Uptd BalPitriyani, Halim, A., \& Hasibuan, D. (2019). Pengaruh Pengalaman Kerja, Latar Belakang Pendidikan Dan Kompensasi Terhadap Kinerja Karyawan Pada Pt. Pegadaian Persero Ca," pp. 1-13, 2019.

[15] U. Rahardja, N. Lutfiani, and M. S. Alpansuri, "Pemanfaatan Google Formulir Sebagai Sistem Pendaftaran Anggota Pada Website Aptisi.or.id," Sisfotenika, vol. 8, no. 2, p. 128, 2018, doi: 10.30700/jst.v8i2.401. 